\title{
O DIÁLOGO ENTRE ARTE E ARQUITETURA NO MODERNISMO EM FORTALEZA ${ }^{1}$
}

\section{DIÓGENES, BEATRIZ HELENA NOGUEIRA}

Doutora em Arquitetura e Urbanismo FAUUSP, Professora/Pesquisadora DAU-PPGAU+D-UFC, bhdiogenes@yahoo.com.br

\section{PAIVA, RICARDO ALEXANDRE}

Doutor em Arquitetura e Urbanismo FAUUSP, Professor/Pesquisador DAU-PPGAU+D-UFC, paiva_ricardo@yahoo.com.br

\begin{abstract}
RESUMO
O objetivo deste artigo é evidenciar o campo ampliado da arquitetura através da análise do diálogo entre o modernismo arquitetônico e artístico, enfatizando as vertentes de integração entre arte e arquitetura no contexto do desenvolvimento do modernismo em Fortaleza. Para tanto, o trabalho pretende elaborar algumas considerações teóricas e conceituais sobre o tema da integração e síntese das artes na arquitetura moderna brasileira; verificar como essa tendência ocorreu na cidade de Fortaleza, articulando com o cenário das artes plásticas à época; para finalmente analisar algumas das obras arquitetônicas modernas construídas nas décadas de 1960 e 1970 , que ostentam expressivos murais, esculturas e intervenções de paisagismo. A pertinência do trabalho se justifica em função dos escassos estudos sobre a matéria no contexto da historiografia da arte e da arquitetura moderna em Fortaleza, constituindo uma contribuição e esforço de documentação e consequente valorização e conservação deste legado.
\end{abstract}

PALAVRAS-CHAVE: arte, arquitetura moderna, síntese das artes, patrimônio moderno, Fortaleza.

\section{ABSTRACT}

The aim of this article is to highlight the broad field of architecture through the analysis of the dialogue between architectural and artistic modernism, emphasizing the integration between art and architecture in the context of the development of modernism in Fortaleza. Thus, the work intends to elaborate some theoretical and conceptual considerations on the theme of the integration and synthesis of the arts in modern Brazilian architecture; analyzing how this trend occurred in the city of Fortaleza, coordinated with the scene of fine arts at the time; to finally look at some modern architectural works built in the 1960 s and 1970s, which bear expressive decorative panels, sculptures and landscaping interventions. The relevance of this work is justified due the fact that there are just a fewstudies on the subject in the context of the history of art and modern architecture in Fortaleza. Therefore, this paper is acontribution and documentation effort, also adding to development and preservation of this legacy.

KEY-WORDS: art, modern architecture, synthesis of the arts, modern heritage, Fortaleza (Ceará-Brazil).

1 Visando ampliar a discussão da temática em pauta, este artigo revisa o texto "A SÍNTESE DAS ARTES NA ARQUITETURA MODERNA EM FORTALEZA", apresentado e publicado nos Anais do $11^{\circ}$ Seminário DOCOMOMO Brasil, acontecido em Recife/2016. 


\section{INTRODUÇÃO}

A importância e a eficácia da integração ou síntese entre arte e arquitetura, embora remonte à gênese da atividade, adquire, desde as vanguardas artísticas do início século XX, um significado e função sociais condizentes (negando ou afirmando) com o processo de reprodução do capitalismo industrial, constituindo um ponto de interseção que caracteriza o Movimento Moderno, presentes nas proposições de Walter Gropius, Mies van der Rohe e Le Corbusier, só para citar os mais destacados representantes.

No processo de disseminação da arquitetura moderna no Brasil, a cooperação entre as artes foi preconizada por vários arquitetos e as manifestações da arte, expostas em murais, pinturas, painéis e vitrais, esculturas, além de jardins, foram incorporadas a uma série de obras construídas em vários lugares onde o modernismo arquitetônico se desenvolveu.

Em Fortaleza, esta tendência se iniciou desde fins da década de 1950, com a chegada dos primeiros arquitetos, diplomados em outros centros, que passam a dialogar com artistas modernos locais. Um aspecto a se considerar é que, tal como aconteceu em outras regiões, é sempre o autor do projeto que comanda o processo de participação de artistas plásticos e paisagistas no conjunto da obra, indicando as diretrizes e o local onde será feita a intervenção.

Embora a arte moderna em Fortaleza esboce seus primeiros passos como movimento na década de 1940, em torno do Centro Cultural de Belas Artes, que dá origem à Sociedade Cearense de Artes Plásticas - a SCAP, com a atuação de Mário Barata (1915-1983), Aldemir Martins (1922-2006) e Antônio Bandeira (19221967), somente na década de 1950 se percebe uma maior assimilação desta produção pela elite intelectual, sobretudo depois da fundação da Universidade Federal do Ceará (UFC) em 1955 e da criação do MAUC Museu de Arte da UFC, que passou a abrigar os acervos e incentivar a produção de artistas modernos.

A participação de artistas cearenses como Zenon Barreto (1918-2002), Sérvulo Esmeraldo (1929-2017) e do paisagista Roberto Burle Marx (1909-1994) em obras de autoria de arquitetos como José Neudson Braga (1935), José Armando Farias (1927-1974) e Acácio Gil Borsoi (1924-2009) constitui alguns dos testemunhos importantes do diálogo entre arte e arquitetura no modernismo em Fortaleza.

Nesta direção, o objetivo do artigo é evidenciar o campo ampliado da arquitetura através da analise do diálogo entre o modernismo arquitetônico e artístico, enfatizando a integração das artes no contexto do desenvolvimento da arquitetura moderna em Fortaleza.

Para tanto, o trabalho pretende elaborar algumas considerações teóricas e conceituais sobre o tema da síntese das artes na arquitetura moderna brasileira; verificar como essa tendência ocorreu na cidade de Fortaleza, articulando com o cenário das artes plásticas à época, para finalmente analisar algumas das obras arquitetônicas modernas construídas nas décadas de 1960 e 1970, que ostentam expressivos murais, esculturas e intervenções de paisagismo.

A pertinência do trabalho se justifica em função dos escassos estudos sobre a matéria no contexto da historiografia da arte e arquitetura moderna em Fortaleza, constituindo uma contribuição e esforço de documentação e consequente valorização e conservação deste legado. 
As proposições teóricas e práticas sobre a síntese das artes estão na origem da arquitetura moderna. Esta integração não ocorre exclusivamente pela unidade fundamental e histórica verificada entre as artes plásticas e pela influência recíproca entre elas, mas expressa uma inovação na visão estética de arte, que busca "estabelecer uma nova linguística, novas semânticas, gramáticas e sintaxes para elaborar um estilo moderno" (ZEVI, 1970, p. 41).

A proposta do "racionalismo metodológico-didático" (ARGAN, 1992), presentes nas premissas conceituais da Bauhaus, apontava em grande medida para a promoção da unidade das artes por meio da "obra de arte total", um dos pressupostos presentes no manifesto da Escola, integrando arquitetura, pintura, escultura, design, ofícios manuais e artesanais. A cooperação entre as artes se verificava ainda no canteiro, articulando o trabalho intelectual e manual, unindo arquitetos e artistas a pedreiros, marceneiros e artífices em uma experiência compartilhada. A síntese das artes na Bauhaus tem como símbolo a catedral, "a imagem renovada de catedral do futuro, catedral do socialismo e assim propondo a unidade entre arte e política" (FERNANDES, 2010, p. 184).

As articulações entre o neoplasticismo holandês e a obra de alguns arquitetos como Gerrit Rietveld, Theo van Doesburg, J. J. P. Oud e Mies van der Rohe, além de designers de mobiliário, demonstravam o entrelaçamento e a influência recíproca dos procedimentos de concepção e do repertório plástico de artistas e arquitetos, que contribuíram sobremaneira para difundir a mudança técnica, funcional, espacial e estética dos artefatos modernos, do objeto à cidade, do plano ao tridimensional, do utilitário ao artístico.

Le Corbusier tem um papel significativo no contexto da síntese das artes modernas, que se justifica porque o próprio arquiteto é também um artista plástico. O Purismo, movimento pictórico empreendido pelo arquiteto-artista em parceria com Amédée Ozenfant, com a difusão dos seus princípios na Revista L'Espirit Nouveau de 1920 a 1925, sofreu forte influência cubista e alimentou as suas proposições na arquitetura em busca da simplicidade das formas elementares. Le Corbusier compreende a arquitetura não somente como expressão do funcionalismo, mas preconiza o seu caráter plástico e artístico, ratificando o seu interesse em estabelecer diálogos entre arte e arquitetura.

No pensamento e na obra destes pioneiros do modernismo, a abstração e a racionalidade constituem as características mais marcantes, tanto da arquitetura como das artes em geral, promovendo, assim, a síntese das artes com o intuito determinado de estabelecer uma tradição da ruptura e consolidar a estética modernista.

No Brasil, o ideal de síntese das artes se insere na constituição da arquitetura moderna desde a sua gênese, influenciado por Le Corbusier. O mestre foi referência para a construção do pensamento arquitetônico moderno no Brasil e despertou, entre os pioneiros modernistas, as possibilidades de incorporação e assimilação de elementos locais e artísticos consoante as intenções de valorização da identidade moderna brasileira à época (BRUAND, 1981).

A arquitetura moderna no Brasil se caracterizou pelo trabalho integrado de arquitetos, pintores, escultores e paisagistas, bem como através da relação com a cultura local, com o propósito de expressar modernidade, tradição e monumentalidade. Lucio Costa, em seu texto de 1936, "Razões da nova arquitetura", destaca que a obra do pintor e do escultor "deveria integrar-se ao conjunto da composição arquitetural como um dos seus elementos constitutivos, ainda que mantivessem autonomia e caráter próprio". Exemplos diversos demonstram a integração entre arte e arquitetura, evidenciando a utilização de elementos formais e plásticos na ordenação e valorização dos espaços, a começar com o paradigmático edifício do Ministério da Educação, primeiro exemplar significativo da nova arquitetura realizada no Brasil, além de obras diversas, como nos complexos modernistas construídos na Pampulha e em Brasília.

No Brasil, algumas realizações como o edifício do MEC, a Igreja da Pampulha (Niemeyer) e o Conjunto Residencial de Pedregulho (Afonso Reidy), foram paradigmáticas dessa integração, influenciando a produção em várias regiões e cidades do país. Deve-se destacar também os jardins de Burle Marx, integrados à arquitetura e ao urbanismo modernos (VELOSO; VIEIRA, 2009, p.5). 
As esculturas, pinturas, murais, vitrais, as artes plásticas em geral, assim como os jardins não são incorporados à arquitetura moderna brasileira como elementos de caráter acessório ou meramente decorativo, mas para reforçar aspectos próprios da fusão entre modernidade, tradição e identidade, ao mesmo tempo em que expressam valores artísticos particulares e autônomos.

Não somente as obras, mas a atuação de importantes arquitetos modernos no ensino da arquitetura nos principais centros urbanos disseminou a síntese das artes como um princípio característico da arquitetura moderna brasileira, influenciando diversos arquitetos, que por seu turno, buscaram incorporar o trabalho de artistas e paisagistas às suas obras em contextos regionais específicos(1).

\section{O CENÁRIO DA ARTE MODERNA EM FORTALEZA}

Até o inicio da década de 1940, o cenário das artes plásticas no Ceará ainda era muito incipiente. Os artistas locais tinham pouco ou quase nenhum contato com os meios artísticos de outros centros - no Brasil e no mundo. As novidades relacionadas à arte moderna chegavam através de livros, revistas e jornais e não havia uma entidade que congregasse os artistas, que atuavam de forma individual e raramente se dedicavam exclusivamente à arte. Havia poucos artistas e eram quase todos ligados à pintura acadêmica, como era o caso de Raimundo Cela, o pintor cearense mais conhecido e bem sucedido, mesmo no cenário nacional, notabilizando-se como exímio desenhista.

Vale destacar, nesse período, a atuação do pintor Vicente Leite, que havia ganhado do governo estadual, ainda na década de 1920, bolsa de estudos para a Escola Nacional de Belas Artes, no Rio de Janeiro e já incorporava valores modernos à sua obra. Recebeu também o prêmio de viagem ao exterior, em 1940, mas não pôde ir devido à guerra. Era paisagista e possuía grande sensibilidade cromática, tendo participado de diversas exposições, coletivas e individuais até 1941, quando faleceu.

A pintura não conheceu então maiores inovações, predominando a confecção de telas com feição academicista, com temas relacionados a naturezas-mortas, flores, retratos, paisagens litorâneas e ao universo dos pescadores.

A centralização do movimento modernista no eixo Rio de Janeiro - São Paulo e as dificuldades inerentes às outras capitais brasileiras contribuíram para as discrepâncias na difusão da estética modernista pelo resto do país (COSTA, 2009, p. 82).

O movimento modernista surge no Ceará na década de 1930, embora mais ligado à literatura e, em menor medida, à arquitetura, mediante exemplares ditos "pré-modernistas", com apoio na estética art-déco, segundo Castro (1994). No que se refere à pintura, foi Mário Baratta, com seu espírito de liderança, o responsável por agrupar, no início dos anos 1940, artistas diversos com o objetivo de desenvolver e incrementar o meio artístico cearense, criando um espaço onde pudessem se reunir para pintar, ler, ministrar palestras e expor seus trabalhos, promovendo um clima de renovaçãoe entusiasmo no ambiente artístico e cultural da capital cearense.

Esse movimento suscitou a criação do Centro Cultural de Belas Artes, o CCBA, fundado em 30 de junho de 1941, que consistiu na primeira entidade de artes plásticas do Ceará e chegou a promover debates artísticos, palestras e exposições, como o Salão Cearense de Pintura, nos anos 1941, 1942 e 1943.

Em 1944, o CCBA uniu-se ao Clube de Literatura e Arte (o grupo CLÃ), originando a Sociedade Cearense de Artes Plásticas, a SCAP, entidade que teve um papel decisivo no desenvolvimento das artes plásticas do Ceará. A SCAP realizou cursos diversos de desenho e pintura e exposições, como o Salão de Abril, criado em 1943 e considerado até hoje como o evento artístico de maior destaque de Fortaleza. O Salão de Abril revelou talentos como Aldemir Martins (1922-2006), Antônio Bandeira (1922-1967), Sérvulo Esmerado (19292017), Zenon Barreto (1918-2002), Jean Pierre Chabloz (1910-1984), Estrigas (1920-2014) e Heloisa Juaçaba (1926-2013), artistas que se destacaram nas décadas seguintes no cenário local e nacional.

Com o tempo, a falta de apoio do governo e as constantes dificuldades financeiras determinaram o fim da entidade, em 1958. Parte do acervo foi acolhidapela Academia Cearense de Letras e parte foi levada para um depósito da Universidade Federal do Ceará. 
O encerramento das atividades da SCAP não foi apenas o fim de uma entidade, representou também um retrocesso de todo um trabalho de mobilização artística iniciado por Mário Baratta. Órfãos, os artistas voltaram ao individualismo de outrora, cada um por si, sem os exercícios conjuntos com modelo vivo, sem a avaliação coletiva dos trabalhos (COSTA, 2009, p. 84).

Com o cenário desfavorável para os artistas, restava-lhes a opção de partirem para o Rio de Janeiro ou São Paulo, onde teriam maiores oportunidades. Ainda na década de 1940, foram para o sul Antônio Bandeira, que posteriormente mudou-se para Paris, Aldemir Martins e Sérvulo Esmeraldo. Outros continuaram na cidade, como Clidenor Capibaribe (Barrica) e Zenon Barreto, que tentavam uma projeção nacional, por meio de exposições em salões e bienais.

Os anos 1940 e 1950, entretanto, marcaram a consolidação das artes plásticas no Ceará, ampliando o quadro de pintores em atividade e divulgando a produção desses artistas pelo país. Como muitos deles ganharam projeção e prestígio nacional, acabaram por influenciar a formação de um "público de arte" na cidade, admirador e consumidor dos trabalhos produzidos à época. Além da pintura, destacam-se trabalhos relevantes de escultura e gravura.

Alguns artistas se apresentam como detentores de láureas nacionais. O prestígio extra-estadual que desfrutam permite-lhes enviar trabalhos para outras regiões do país. Alheios, pois, às variações do mercado e às idiossincrasias da clientela local, já podem, com relativa tranquilidade, dedicar-se profissionalmente à arte (CASTRO, 1994, p. 262).

A criação do Museu de Arte da Universidade Federal do Ceará (MAUC), na década de 1960 foi também fator determinante para o desenvolvimento das artes plásticas na capital cearense. Inaugurado em junho de 1961 pelo então Reitor Antônio Martins Filho (fundador da UFC), o MAUC passou a abrigar os acervos e incentivar a produção de artistas modernos, firmando-se assim "como importante centro de preservação da cultura artística cearense, quer das expressões mais populares quer daquelas de caráter erudito"(2). Inúmeras exposições foram realizadas pelo museu, a maioria de artistas cearenses, atraindo sempre grande número de pintores, escultores, arquitetos e admiradores da arte.

A quantidade de galerias de arte também se expandiu a partir da década seguinte, o que contribuiu para o conhecimento, difusão e consumo da arte local, evidenciando uma maior assimilação desta produção pela elite intelectual.

A penetração dos princípios da arquitetura moderna em Fortaleza ocorreu ainda na década de 1950, com a chegada dos primeiros arquitetos diplomados em outros centros, como Rio de Janeiro, Recife e São Paulo. A construção de obras modernas com caráter mais erudito coexistia com uma "modernidade programática" (SEGAWA, 2002), marcada por influências arquitetônicas de caráter protomoderna e art-déco, produzida por engenheiros e práticos.

Somente com a Escola de Artes e Arquitetura da UFC, criada no ano de 1965 e reconhecida, à época, como o grande centro de referência cultural da Universidade e da Cidade, a arquitetura moderna se consolida como importante movimento de transformação espacial face ao desenvolvimento urbano que a capital cearense testemunhava como importante metrópole regional.

Na década seguinte, já havia um número significativo de obras modernas em Fortaleza, projetadas também pelos egressos da Escola de Arquitetura. A cidade assistiu desde então grande incremento na produção de obras realizadas de acordo com projetos elaborados por arquitetos, iniciando-se uma nova fase na arquitetura cearense.

É importante ressaltar que a incorporação de elementos artísticos na arquitetura moderna em Fortaleza foi iniciativa dos arquitetos locais e de arquitetos de outros estados que atuaram na Cidade, uma vez que o desenvolvimento da arte e da arquitetura moderna acontece de forma independente e paralela.

São vários os exemplos que demonstram tal prática na arquitetura moderna em Fortaleza, evidenciando o emprego de elementos formais e plásticos na ordenação dos espaços e o diálogo entre arte e arquitetura. 
Algumas obras arquitetônicas modernas construídas nas décadas de 1960 e 1970 em Fortaleza ostentam expressivos murais decorativos, esculturas e intervenções de paisagismo, evidenciando uma articulação entre o modernismo arquitetônico e artístico no contexto do desenvolvimento da arquitetura moderna na cidade.

Esse período inaugurou uma prática até então pouco comum na cidade: a inserção de trabalhos artísticos em edificações, ação incentivada sobretudo pelo poder público, que passou a encomendar obras de arte que tratassem de tipos e temas populares para ornamentar seus edifícios, embora essa tendência tenha se estendido também a projetos da iniciativa privada.

A obra de arte passa, então, a adquirir maior relevância no contexto urbano e arquitetônico, ora através de murais ${ }^{(\mathbf{3})}$ em fachadas, ora através de pinturas e esculturas, criando uma interação entre o artista e o público, entre a arte e o habitante da cidade e usuário da edificação. A participação de artistas cearenses como Zenon Barreto, Sérvulo Esmeraldo e do paisagista Roberto Burle Marx, entre outros, em obras de autoria de arquitetos como José Neudson Braga, José Armando Farias e Acácio Gil Borsoi constitui testemunho importante da integração das artes na arquitetura moderna em Fortaleza. Algumas dessas obras emblemáticas foram selecionadas e serão analisadas a seguir.

\section{Centro dos Exportadores do Ceará e o mural "Estivadores"}

O projeto do Centro de Exportadores do Ceará, de autoria do arquiteto Neudson Braga, foi elaborado em 1962. Localiza-se em um terreno irregular na Av. Alberto Nepomucemo, no Centro, nas proximidades da antiga área portuária da cidade. Sua volumetria é composta de uma base irregular, com térreo e mais dois pavimentos, que ocupa toda a área do lote (de esquina) e um bloco prismático regular, que se desenvolve em quatro pavimentos, voltado para a avenida principal.

A base apresenta bastante simplicidade, rompida pelo mural artístico localizado na esquina -"Os Estivadores"(4), do artista plástico Zenon Barreto, caracterizando a influência da busca de síntese das artes presente na arquitetura moderna brasileira. A concordância em curva e contra-curva do mura|(5) faz referência ao Edifício Seguradoras, dos irmãos Roberto no Rio de Janeiro de 1949 (GABRIELE, 2006).

O mural "Os Estivadores", elaborado com pequenas pastilhas coloridas, possui grande expressão plástica e faz referência à atividade portuária da cidade, retratandoos trabalhadores do porto, por meio deformas simplificadas e composição geometrizada. A temática faz parte da tendência observada à época de exaltação do trabalhador brasileiro, utilizada já por Cândido Portinari(6), entre outros, em várias obras de sua autoria. O azul, em várias tonalidades, é a cor predominante adotada.

"Os Estivadores" é obra emblemática do artista, que foi também pintor, desenhista, gravador, escultor, cenografista e ilustrador. Zenon Barreto foi responsável por outras obras relevantes, que fizeram parte da composição de alguns dos edifícios modernos construídos à época, em Fortaleza, como o mural "Trabalhando no campo", do DAER, que será enfocado a seguir, o mural "Jangadas" (Figura 1), que compõe a fachada do Museu de Arte da UFC, além de quatro esculturas instaladas ao ar livre, nos jardins do Palácio da Abolição, sede do governo do Estado, cujos temas remetem a mulheres e seus ofícios típicos do Ceará: "A Rendeira", "Pilando", "Mulher com pote" e "Cafuné". As esculturas valorizam personagens e tipos femininos caros ao imaginário popular nordestino (COSTA, 2009).

Durante toda a década de 60, [Zenon Barreto] continuou a produzir murais que buscavam ilustrar o desenvolvimento e o progresso do Estado (...) O mural "Os Estivadores" segue o mesmo estilo do mural do DAER, com sua composição geometrizada, linhas simples, sem grandes detalhes e sempre mostrando os operários trabalhando incessantemente (COSTA, 2009, p. 4).

A obra teve o seu uso prejudicado pela passagem de um viaduto, que compunha um trecho elevado da Av. Leste-Oeste, deprimindo as áreas próximas, aliado ao processo de decadência das áreas centrais verificadas em diversas cidades do Brasil. O abandono do edifício do Centro de Exportadores do Ceará desde meados 
de 1997, quando já era sede do Banco do Ceará (BANCESA), se enquadrou neste contexto de mudanças dos atributos de centralidade do centro de Fortaleza e das novas dinâmicas urbanas e metropolitanas (PAIVA; DIÓGENES, 2012).

Figura 1 - Mural "Jangadas" Museu de Arte de Fortaleza (década de 1960) e atualmente

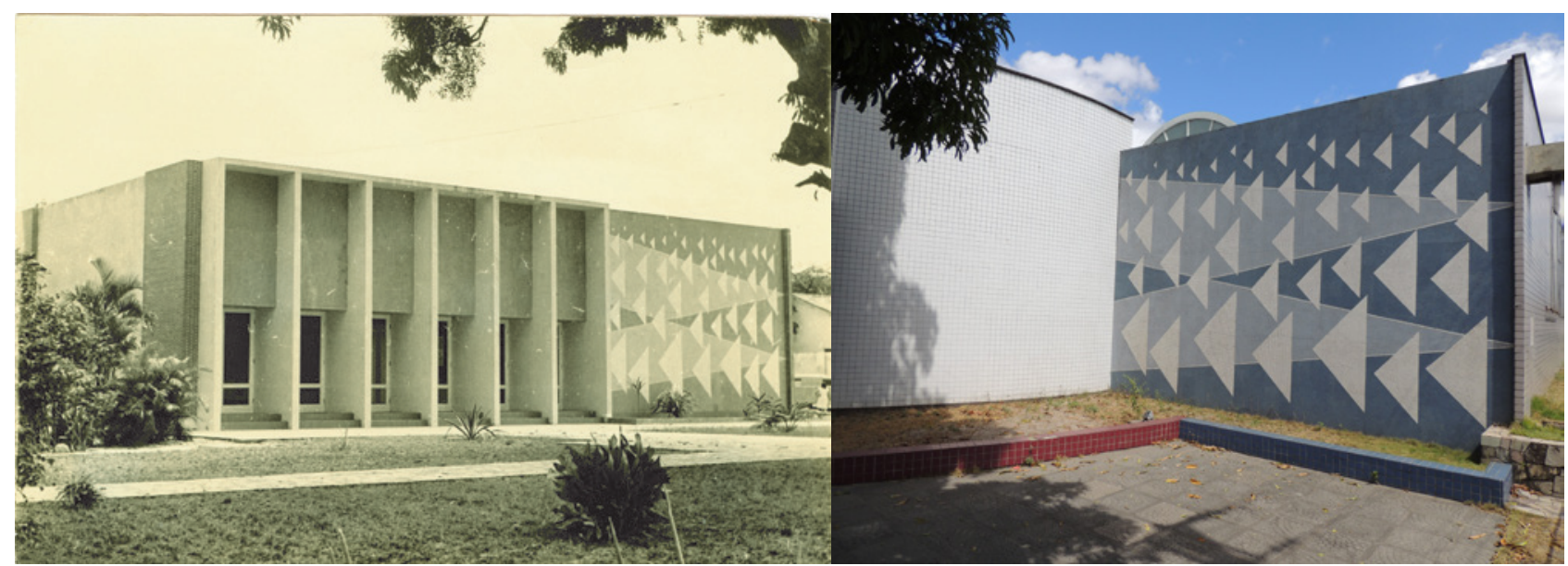

Fonte: MAUC-UFC/Acervos dos autores

O edifício ficou desocupado por muitos anos, o que resultou em grande prejuízo, decadência e deterioração do conjunto, inclusive do painel, que ficou praticamente destruído (Figura 2), assim permanecendo até o início dos anos 2000, quando foi adquirido pela Secretaria da Fazenda do Governo do Estado do Ceará (SEFAZ-CE). Devido à necessidade de ampliação das suas instalações, foi feita a licitação do projeto de reabilitação, no ano de 2005.

Figura 2 - Mural "Os Estivadores" Centro de Exportadores do Ceará (1962) - Fim da década de 1990 em estado de degradação

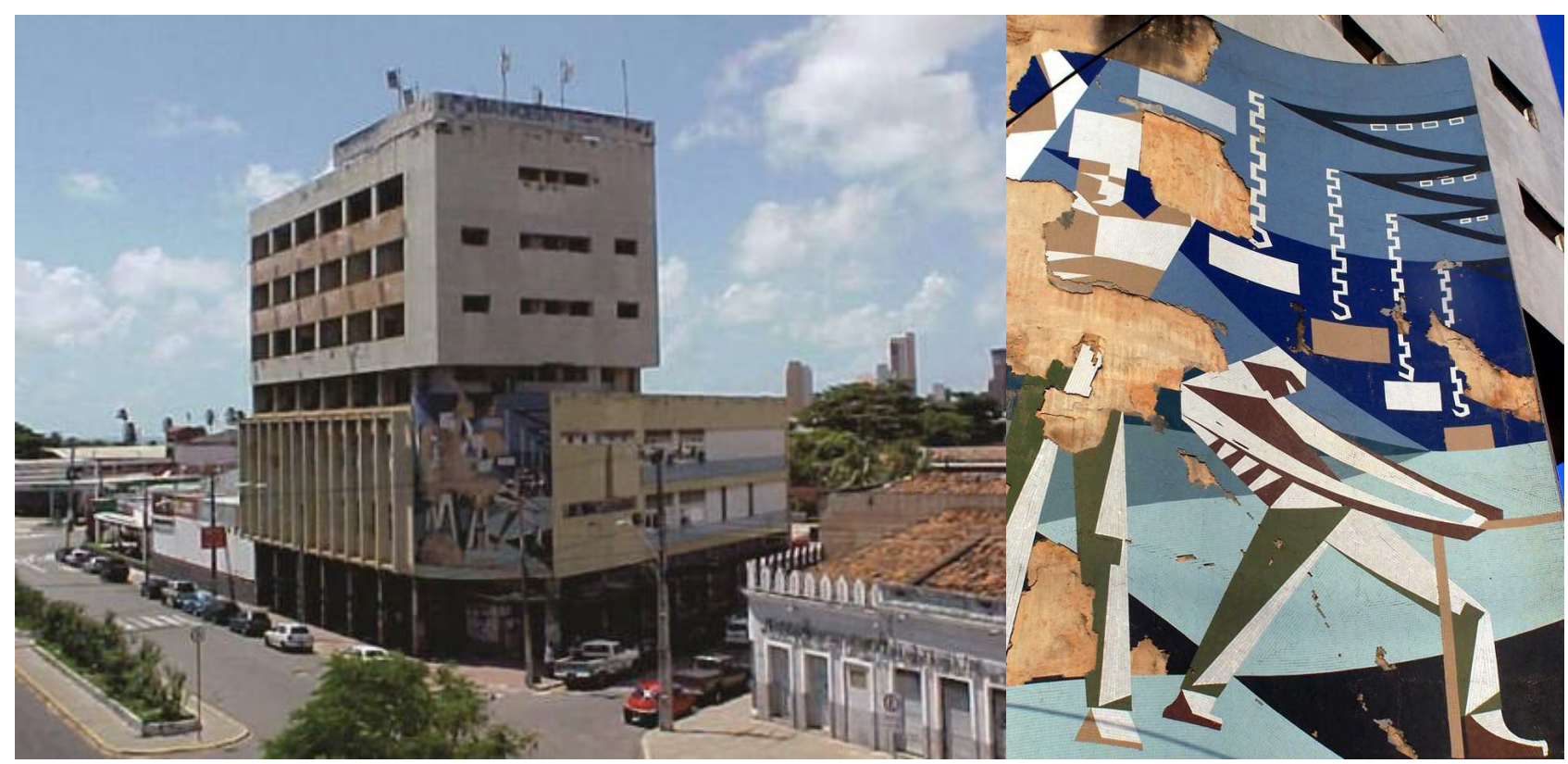

Fonte: Acervo dos autores

O projeto de retrofit, elaborado de maneira rigorosa, atentou para a necessidade de respeitar as características do projeto original e merece, portanto, ser destacado como procedimento de relevante interesse. O projeto de intervenção manteve a volumetria original, havendo mudanças apenas na utilização dos materiais de revestimento, embora se tenham mantido características similares, inclusive nas cores, como é o caso do revestimento cerâmico. Apenas as esquadrias utilizadas apresentam uma aparência mais distanciada das especificações originais, antes compostas de folhas intercaladas de madeira e vidro e venezianas eatualmente substituídas por alumínio e vidro. 
A inserção urbana do edifico reabilitado possibilitou o dinamismo da área, com o restabelecimento do uso, potencializado pela presença de outros edifícios da SEFAZ nas proximidades, suscitando novos fluxos. Tratase também de um exemplo da necessidade de estimular o retorno de sedes de instituições públicas para o Centro que, em um "efeito cascata", estimula o surgimento de espaços terciários privados (comércio e serviços). Colaborou para a reabilitação do edifício a restauração do mural artístico (Figura 3), elaborada de maneira cuidadosa, em obediência ao desenho origina|(7). A recuperação da obra (8) de Zenon Barreto restabelece a memória do artista e evidencia o caráter público da arte urbana, servindo de modelo para novas intervenções em edifícios modernos e históricos em geral.

Figura 3 - Mural "Os Estivadores" Centro de Exportadores do Ceará (1962) - Fotos atuais pós retrofit

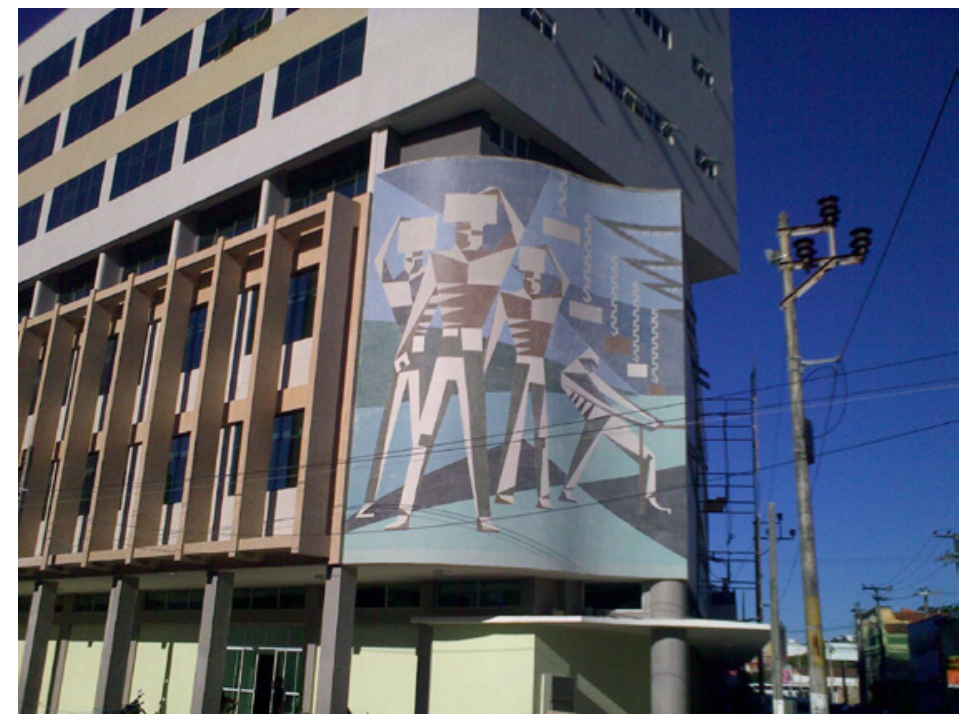

Fonte: Acervo dos autores

\section{O edifício do DAER e o mural "Trabalhando no campo" (1962)}

Outro exemplar emblemático da arquitetura moderna cearense, o edifício do Departamento Autônomo de Estradas e Rodagem (DAER, atual Procuradoria Geral de Justiça do Ministério Público) também ostenta um mural do artista plástico Zenon Barreto, realizado quase à mesma época que "Os Estivadores".

O projeto, elaborado em 1962, de autoria do arquiteto José Armando Farias (1927-1974), apresenta uma implantação tipicamente moderna, traduzida na inserção do edifício solto em meio a uma quadra inteira e na adoção de pilotis no bloco principal (Figura 4). Esse partido possibilitou uma circulação livre ao nível do solo, diluindo as barreiras espaciais entre os domínios público e privado (PAIVA; DIÓGENES, 2014).

Figura 4 - Departamento Autônomo de Estradas e Rodagem (DAER, 1962) - Atual Procuradoria Geral de Justiça do Estado do Ceará

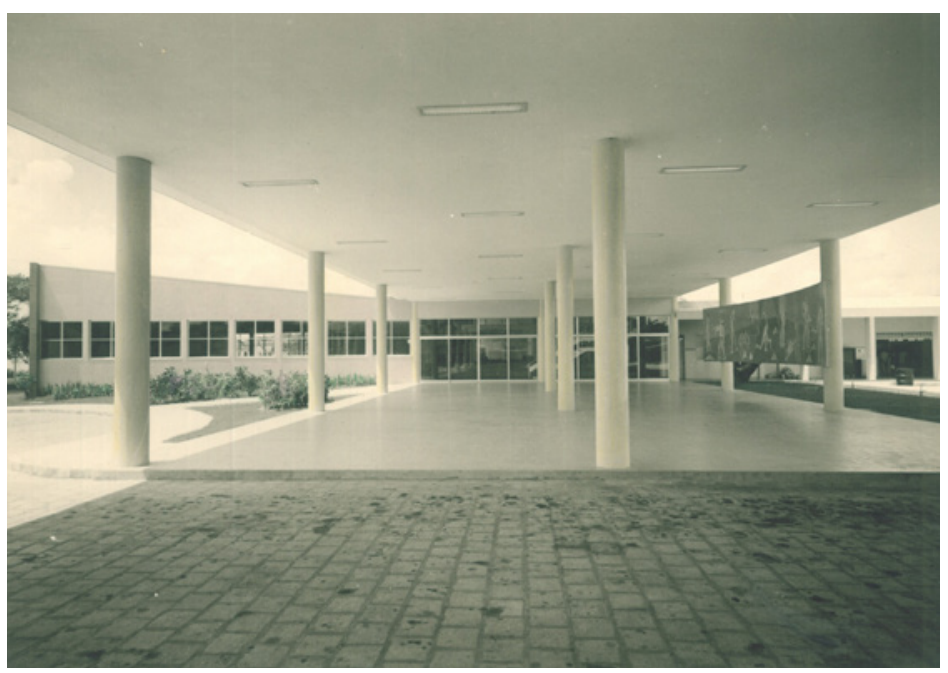

Fonte: Acervo Memorial José Armando Farias 
Os elementos estruturais (pilares e vigas) e as vedações (alvenarias e esquadrias) são bem definidos e obedecem à trama modular proposta pelo arquiteto. O térreo e as áreas não edificadas foram valorizados com a criação de uma escultura de ferro e com o tratamento paisagístico, com linhas geométricas, espelhos d'água e a utilização de espécies vegetais nativas.

Outra herança modernista visível no edifício se refere à sua intenção de promover a integração das artes. No pilotis foi concebido um mural - "Trabalhando no Campo"(9) (Figuras 5 e 6) - do artista plástico Zenon Barreto, compreendido como "uma homenagem aos homens que abriam os caminhos para o desenvolvimento do estado com a construção de estradas" (COSTA, 2014, p. 106).

O artista participou de um concurso(10) promovido pelo Departamento Autônomo de Estradas e Rodagens (DAER) para a construção de um painel para a nova sede da instituição, conquistando o primeiro lugar. A obra mostra homens nas mais variadas funções, trabalhando incessantemente na construção de uma estrada, símbolo do progresso para um Estado que até pouco tempo sobrevivia da agricultura. O título Trabalhando no Campo também sugere essa ideia de desenvolvimento, ao mostrar a mudança das atividades laboriosas no meio rural. No lugar de agricultores, o que vemos são operários da construção civil, atividade tipicamente urbana (COSTA, 2010, p. 37).

O mural está localizado entre os pilares do térreo, apresenta forma ligeiramente curva e foi produzido com pastilhas de porcelana coloridas, técnica já utilizada pelo artista em outros murais na Cidade. A pesquisadora Sabrina Costa, estudiosa da obra de Zenon Barreto faz uma análise da obra:

No que concerne à obra propriamente dita, prevalece o geometrismo tanto na composição do painel quanto na forma das figuras humanas. As linhas que saem das extremidades e convergem no centro do painel ao mesmo tempo em que dividem os planos dão profundidade à narrativa. A disposição das figuras permite uma fruição isolada de cada personagem e contribui para a simetria da obra. Os homens são fortes, robustos e não aparentam cansaço, mesmo quando interrompem a labuta para se refrescarem. As figuras humanas não possuem detalhes, mas exprimem um vigor físico e uma concentração em suas atividades (COSTA, 2014, p. 107).

Segundo Jaqueline Medeiros (2012), a obra de Zenon Barreto "se caracteriza pela busca de novos significados e pela confrontação dos limites da relação dos temas identitários locais com o pensamento moderno e construtivo"(11).

"Trabalhando no campo" permanece em muito bom estado no acesso ao prédio, mesmo depois de várias alterações e reformas na edificação, como a colocação de um gradil e a implantação de estacionamentos, que subtraíram de alguma forma a visibilidade pública da obra.

Figura 5 - Mural Artístico "Trabalhando no Campo" - Zenon Barreto (DAER (1962)

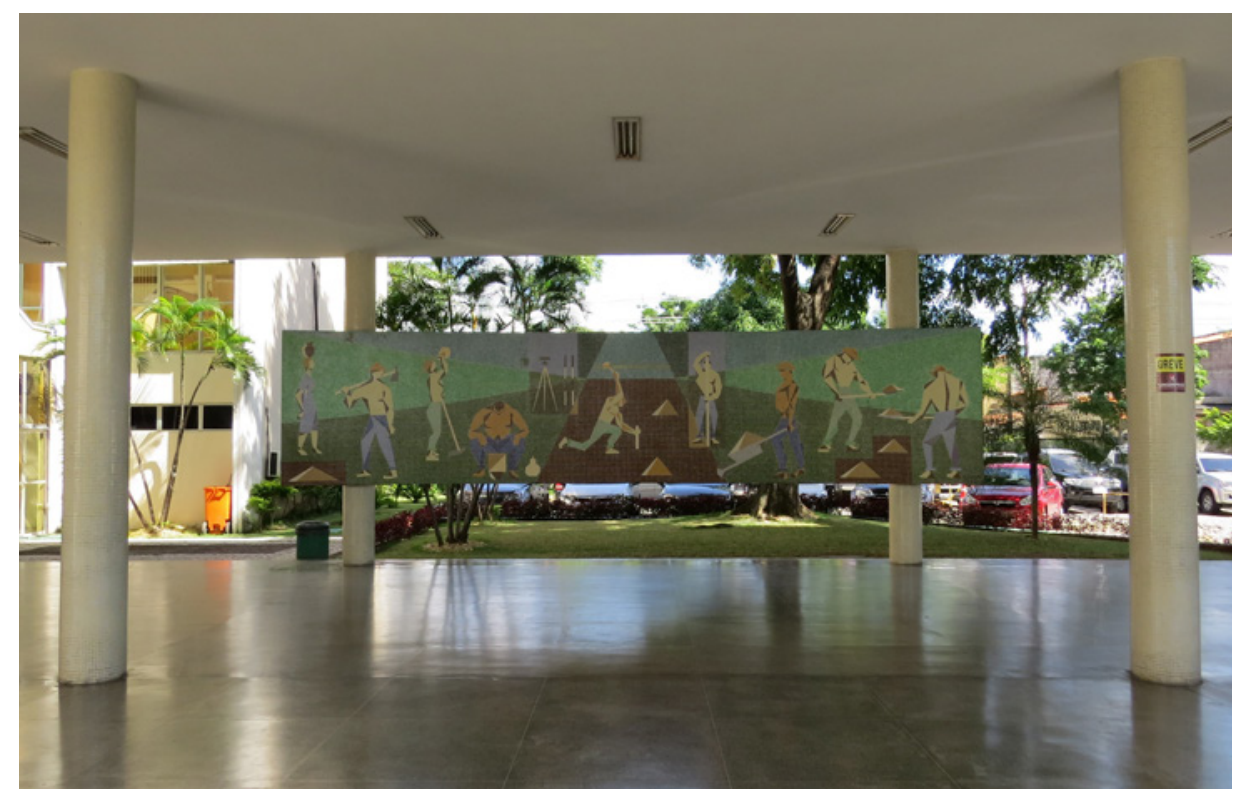

Fonte: Yasmin Rodrigues 
Figura 6 - Detalhe Mural Artístico "Trabalhando no Campo" - Zenon Barreto (DAER (1962)

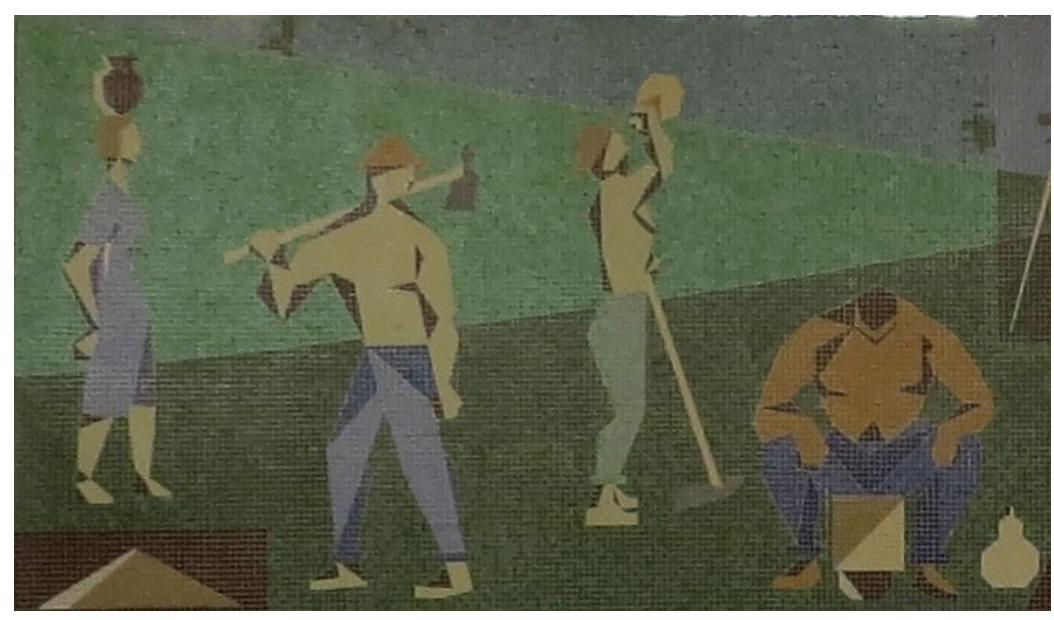

Fonte: Yasmin Rodrigues

\section{Residência Benedito Macedo (1968): um exemplo de síntese das artes em Fortaleza}

O projeto residencial remanescente mais significativo de Acácio Gil Borsoi em Fortaleza é a Residência Benedito Dias Macedo (1968), que teve seu uso alterado em fins da década de 1970, passando a funcionar como sede do grupo J. Macedo. Atualmente, embora ainda pertença à família, não abriga mais nenhuma atividade, estando desocupado há alguns anos. Trata-se de uma obra de caráter privado, onde houve uma visível preocupação em conciliar a arquitetura com outras manifestações de arte plástica.

O terreno ocupa toda uma quadra no bairro da Aldeota, em Fortaleza, zona residencial de alta renda da Cidade, que tem passado nas últimas décadas por processo intenso de transformações no que se refere ao uso e ocupação do solo, transformando-se num dinâmico centro de comércio e serviços da cidade, voltado principalmente para a elite abastada.

As soluções arquitetônicas, como o concreto aparente, os brises, a laje impermeabilizada, o pilotis, os balanços, remetem claramente ao repertório da arquitetura moderna brasileira. Ao mesmo tempo, é perceptível o atendimento às necessidades funcionais e culturais demandadas pelas especificidades do local, como é o caso da presença das varandas, de generosas áreas sombreadas, da utilização de cobogós, do emprego da madeira e da pedra. A integração entre os elementos arquétipos da arquitetura moderna brasileira e a consciência do lugar revela uma das preocupações recorrentes na trajetória do arquiteto: promover a identidade por intermédio da valorização da tradição cultural do Nordeste.

Com a mudança de uso, em fins da década de 1970, houve a necessidade de ampliação de área física, necessária para atender ao novo programa da sede do Grupo Empresarial J. Macedo e foi construído, em 1978, um outro bloco no terreno (projeto também de Borsoi) com três pavimentos e pilotis, que ocupa a face oeste do terreno. O acréscimo, entretanto, não significou descaracterização do conjunto que, ao contrário, conserva equilíbrio harmonioso, ao adotar a mesma linguagem da residência, diferenciando-se desta pela verticalização.

O paisagismo de Burle Marx é um atrativo à parte no complexo, constituindo verdadeira obra de arte. A intervenção de Burle Marx (Figura 7) pode ser considerada a primeira experiência erudita no campo do paisagismo em Fortaleza, muito embora sua repercussão tenha se restringido ao ambiente privado e alheio às atividades dos arquitetos locais, que não incluíam o projeto de paisagismo no conjunto arquitetônico.

Com desenho elaborado, os canteiros sinuosos, a paginação do piso, os espelhos d'água, a criação de elevações na topografia e a vegetação que compõem o projeto são concebidos de forma a por em evidência a arquitetura da residência. A associação de linhas curvas e retas dos canteiros e espelhos d'águacontrapõe-se à ortogonalidade predominante da edificação, procedimento adotado com frequência pelo paisagista na maioria de seus projetos (DIOGENES; PAIVA, 2007, p.4). 
Além do paisagismo, o projeto de interiores estabelece uma relação de complementaridade à arquitetura. Em parceria com Borsoi ou individualmente, a arquiteta Janete Costa (1932-2008) foi, como em outros projetos, a responsável por propor uma atitude inteiramente inovadora e moderna na arquitetura de interiores. Dotada de uma sensibilidade artística e técnica refinada, a arquiteta concebe e desenha ambientes e mobiliários com grande sofisticação e simplicidade, incorporando obras de artistas eruditos e populares sem distinção, que valorizam sobremaneira os espaços. Na Residência Benedito Macedo introduz painéis cerâmicos do artista plástico Francisco Brennand (1927) e escultura do artista cearense Sérvulo Esmeraldo (1929), além de vitrais, cujo desenho é da própria arquiteta e da artista plástica Mariane Peretti (Figura 8). A síntese entre a arquitetura e as artes aplicadas agrega significativo valor estético à obra.

A residência conta também com a obra "Montanha" (Figura 9), do célebre escultor Bruno Giorgi, localizada no jardim de Burle Marx e premiada na II Bienal de São Paulo de 1952.

A existência desta e de outras obras de arte, como no caso dos painéis cerâmicos de Francisco Brennand (um no interior da casa e outro na parede externa da sala de jantar), voltado para os jardins e servindo de fundo para as plumérias; e o vitral que oferece iluminação colorida à articulação de circulações internas da residência, de provável autoria de Marianne Peretti, itens que enfatizam o espírito moderno ali presente, sob os mais variados aspectos (ROCHA, 2014, p.112).

Figura 7 - Proposta inicial para os jardins da residência Benedito Macedo

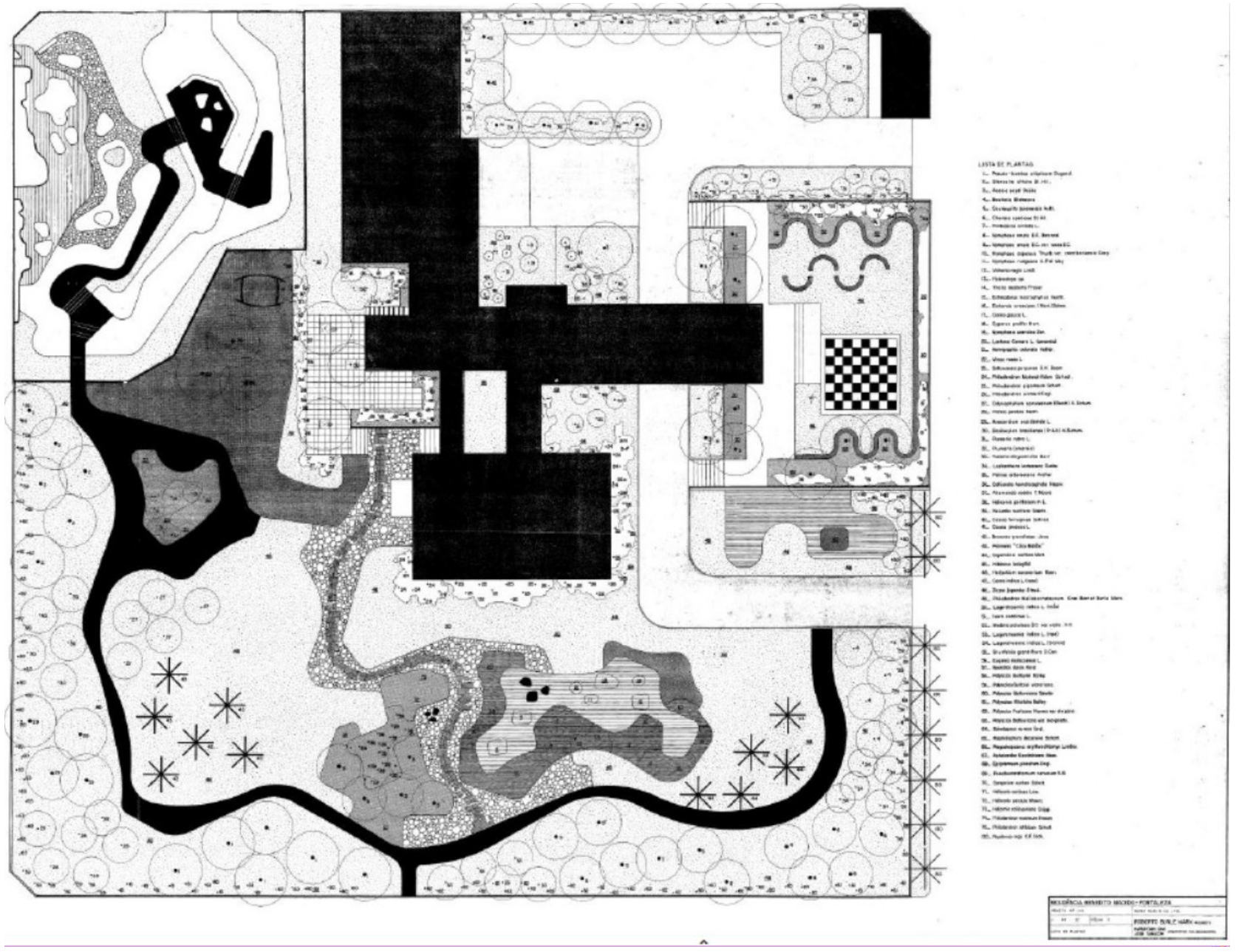

Fonte: Escritório Roberto Burle Marx ROCHA (2014) 
Figura 8 - Vitral de Marianne Peretti

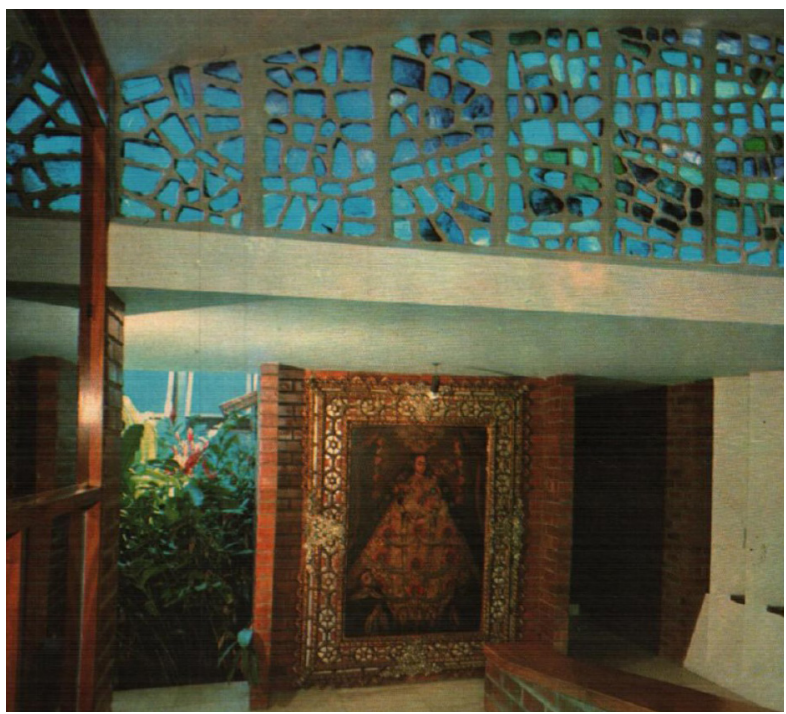

Fonte: Revista Casa \& Jardim (ROCHA, 2014)
Figura 9 - Escultura "Montanha" de Bruno Giorgi e vitral de Marianne Peretti

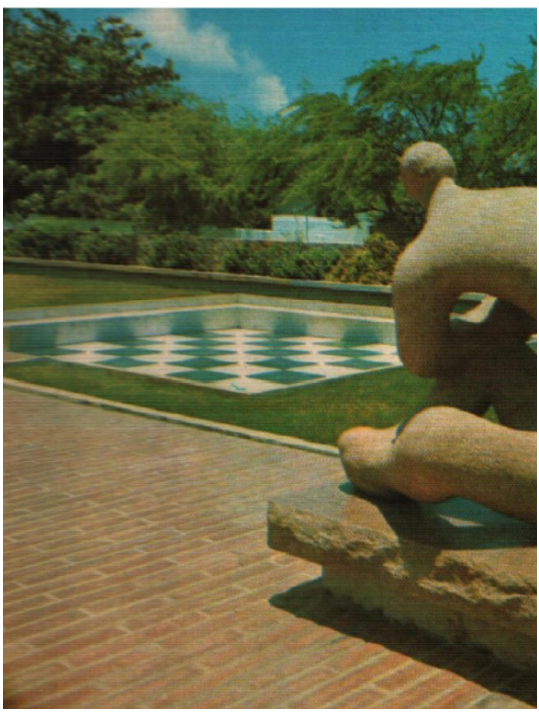

Fonte: Revista Casa \& Jardim (ROCHA, 2014)

Enfim, a síntese das artes verificada na Residência Benedito Macedo representa uma manifestação da maneira como as classes mais altas (no caso da família Macedo, ligada à indústria) se apropriam do repertório moderno arquitetônico, paisagístico e artístico como forma de legitimação do seu prestígio econômico e social, estabelecendo intercâmbios com arquitetos, paisagistas e artistas de relevância nacional.

\section{CONSIDERAÇÕES FINAIS}

O tema da síntese das artes é recorrente no estudo da arquitetura moderna no Brasil. Este artigo, embora não tenha a pretensão de esgotar o assunto, traz uma contribuição para o estudo das especificidades da integração entre arte e arquitetura no contexto específico do desenvolvimento do modernismo arquitetônico e artístico na cidade de Fortaleza.

Com a divulgação e análise das obras, é possível inferir que a arquitetura moderna praticada por arquitetos locais e de outros estados herda da matriz do modernismo arquitetônico o interesse em promover uma integração entre arte e arquitetura. Na esfera pública, esta incorporação tem grande apelo simbólico, posto que os edifícios e os murais analisados representam um esforço de modernização do Ceará e de sua capital, presentes na função pública dos edifícios e nos temas concebidos e executados por Zenon Barreto em "Os Estivadores" e "Trabalhando no Campo", constituindo assim um legado para arte pública de Fortaleza. Na esfera privada, percebe-se que a classe dominante cumpre um papel de "mecenas" ou de incentivadores do desenvolvimento artístico, encomendando projetos de arquitetura e ambientação, jardins e obras de arte, ao mesmo tempo em que é perceptível que este consumo das artes potencializa o seu status social de agentes da modernização, como é o caso da família Macedo.

Entretanto, é preciso admitir que a síntese das artes na arquitetura moderna em Fortaleza acontece de forma isolada e em situações particulares e circunstanciais, não constituindo um movimento institucionalizado na Universidade, nos museus, mostras e galerias de arte. Das obras analisadas pode-se concluir que, mais que uma "síntese das artes", é possível constatar a "presença" da arte em alguns exemplares, como no Centro dos Exportadores e no edifício do DAER. Apenas na residência de Benedito Macêdo se pode perceber uma intenção de estabelecer essa integração de forma plena, com a inserção de obras de arte diversas, que dialogam com a arquitetura.

Somente na década de 1990 a articulação entre arte e arquitetura em obras públicas adquire um viés mais formal: 
Supomos que uma das razões que suscitaram aparceria arquitetura-artes plásticas foi a sanção da lei municipal 7503/94, que determina a obrigatoriedade de obras de arte em edificações públicas na capital cearense. Embora restrita a edificações públicas, não se pode descartar o impacto que ela teve no mercado de arte local (COSTA, 2014, p. 86).

Enfim, este artigo, ao registrar este legado, busca chamar a atenção para a necessidade de preservação da produção da arquitetura e da arte moderna em Fortaleza, assim como a trajetória de arquitetos e artistas, preconizando que a documentação é um pressuposto para a preservação deste acervo.

\section{REFERÊNCIAS}

ARGAN, G. C. Arte Moderna. São Paulo: Cia das Letras, 1992.

BRUAND, Y. Arquitetura contemporânea no Brasil. São Paulo: Perspectiva, 2010.

CASTRO, José Liberal de. Estado atual das pesquisas em artes plásticas no Ceará. In: Revista do Instituto do Ceará. Fortaleza, 1994.

COSTA, Sabrina A. A. O Artista Zenon Barreto e a arte pública em Fortaleza. Fortaleza: BNB Brasil, 2014.

COSTA, Sabrina A. A. O meio artístico cearense em meados do século XX. In: V ENCONTRO DE HISTORIA DA ARTE. Anais do ..... Campinas: IFCH/UNICAMP, 2009, s/p.

DIOGENES, B. H.; PAIVA, R. P. Jardins de Burle Marx em Fortaleza. In: Encontro Regional Paisagem na Históriajardins e Burle Marx no Norte e Nordeste. Anais do ....., Recife: UFPE, 2007, s/p.

FERNANDES, F. Síntese das Artes e cultura urbana. Relações entre arte, arquitetura e cidade.. In: SEGRE, Roberto; AZEVEDO, Marlice; COSTA, Renato Gama-Rosa; ANDRADE, Inês El-Jaick. (Org.). Arquitetura+arte+cidade: um debate internacional. Rio de Janeiro: Viana\&Mosley / Prourb, 2010, v. , p. 180-188.

GABRIELE, M. C. F. L. Neudson Braga e a construção de uma arquitetura moderna no Ceará. In: $1^{\circ}$ DOCOMOMO NORTE E NORDESTE. Anais do ..., Recife: UNICAP/UFPE, 2006.

PAIVA, R. A.; DIOGENES, B. H. Caminhos da Arquitetura Moderna em Fortaleza: a contribuição do professor arquiteto José Neudson Braga. In: $4^{\circ}$ DOCOMOMO NORTE- NORDESTE, 2012, Natal. Anais do .... Natal: UFRN, 2012, s/p.

PAIVA, R. A.; DIOGENES, B. H. Caminhos de Arquitetura Moderna em Fortaleza: A contribuição do arquiteto José Armando Farias. In: $5^{\circ}$ SEMINARIO DOCOMOMO N/NE, 2014, Fortaleza. Anais do ..... Fortaleza: UFC, 2014.

ROCHA, F. C. L. Os jardins residenciais de Roberto Burle Marx em Fortaleza: entre descontinuidades e conexões. Dissertação de Mestrado (Programa em Arquitetura e Urbanismo). Universidade PresbiterianaMackenzie, São Paulo, 2014.

SEGAWA, H. Arquiteturas no Brasil 1900-1990. São Paulo: Editora da Universidade de São Paulo, 2002.

VASCONCELOS, T. A arte pública de Fortaleza. Fortaleza: Criativemidia, 2003.

VELOSO, M.; ARAÙJO, N. M. Arte Moderna na Arquitetura e no Urbanismo recifenses - síntese e paradoxos, no ontem e no hoje: uma análise através de algumas das obras de Abelardo da Hora e Francisco Brennand. In: $8^{\circ}$ SEMINARIO DOCOMOMO BRASIL. Anais do ..... Rio de Janeiro: UFRJ, 2009.

ZEVI, B. História da Arquitectura Moderna. Lisboa: Editora Arcádia, 1970.

\section{NOTAS}

(1) O tema da Síntese das Artes é tão relevante que foi o foco central de discussão no Congresso Internacional Extraordinário de Críticos de Arte. Brasília-São Paulo- Rio de Janeiro, 17 a 25 de setembro de 1959, quando participaram importantes expoentes da história da arquitetura com o Bruno Zevi, MaxBill, Meyer Schapiro, André Bloc, Will Ghromann, entre outros.

(2) www.mauc.ufc.br

(3) Os murais constituem um dos elementos artísticos mais recorrentes incorporados à arquitetura moderna, presentes em espaços internos ou compondo a volumetria dos edifícios. Contribuem ainda para o estabelecimento de um diálogo com a cidade, tornando- 
se muitas vezes importantes marcos urbanos. "Os murais na arquitetura e o uso da cor, com todas as potencialidades que Ihe são conferidas a partir dos estudos de seus efeitos no espaço e no psiquismo humano, passam a identificar a solução mais usual de síntese das artes, na relação entre arte, arquitetura e ambiente urbano" (FERNANDES, 2010, p. 184).

(4) Dados obra 'Estivadores' (1963) - Autor: Zenon Barreto; Material: Painel em Pastilhas dePorcelana; Dimensões: 7,30 x 8,70 m; Localização: Antigo Centro dos Exportadores do Ceará, atual Secretaria da Fazenda do Governo do Estado do Ceará (SEFAZ-CE); Fortaleza-CE. (COSTA, 2014, p. 109).

(5) A parede curva foi concebida pelo arquiteto para ostentar uma obra de arte e, neste sentido, convidou ele mesmo o artista plástico Zenon Barreto para executar um mural neste espaço.

(6) O artista representou em suas obras vários ciclos econômicos do Brasil, através dos seringueiros, garimpeiros, plantadores de café, fumo, algodão, erva mate, cacau, entre outras culturas.Portinari possui muitas de suas obras em edifícios emblemáticos do modernismo arquitetônico brasileiro, como o Edifício do Ministério de Educação e Saúde e a Igreja da Pampulha.

(7) A restauração foi feita a partir de um estudo do painel encontrado na residência de Zenon Barreto e cedido pela família do artista, embora se tenham observado pequenas diferenças entre o painel executado e o estudo original.

(8) “Um pedaço da memória das artes cearenses foi recuperado. O painel 'Os Estivadores', do artista plástico Zenon Barreto, pode ser apreciado na fachada do prédio da Secretaria da Fazenda do Estado (SEFAZ), no Centro, inaugurado ontem à tarde. A obra estava incompleta, com partes faltantes e cenário em lacunas. Foi restaurada, em uma parceria com a Secretaria da Cultura do EStado (SECULT) e agora é ponto importante para o resgate da história das artes no Ceará" (Jornal O POVO, abril de 2009).

(9) Dados da obra 'Trabalhando no Campo' (1960/ 1961) - Autor: Zenon Barreto; Material: Muralem Pastilhas de Porcelana; Dimensões: 9,70 × 2,15 × 0,065 m; Local: DAER-atual sede da Procuradoria Geral de Justiça do Ceará (PGJ); Fortaleza-CE. (VASCONCELOS, 2003, p.22).

(10) O edital do concurso, publicado no jornal "Gazeta de Notícias"em 10 de agosto de 1960, especificava tema, material e dimensões: "O Departamento Autônomo de Estradas e Rodagens do Ceará convida os artistas plásticos, para participarem de um concurso de projetos, para um painel a ser executado em pastilhas, sobre uma laje vertical curva, com as dimensões: 9,40 × 2,10 m e uma flecha de 0,30 m. O painel deverá apresentar um motivo rodoviário".

(11) Jornal "O Povo", 25/02/2012.

NOTA DO EDITOR (*) O conteúdo do artigo e as imagens nele publicadas são de responsabilidade do(s) autor(es). 